JERZY KAŁĄŻNY

Uniwersytet im. Adama Mickiewicza w Poznaniu

\title{
Literatura niemiecka po przełomie 1989/1990 roku. Przypadek Dursa Grünbeina
}

\section{Krajobraz literacki po przełomie}

Przełom lat 1989/199o i zjednoczenie Niemiec przyniosły także gruntowne przemeblowanie niemieckiej sceny literackiej polegające na scaleniu dwóch literatur, które od końca lat czterdziestych rozwijały sie osobno. Początek lat dziewięćdziesiątych $\mathrm{xx}$ wieku to okres intensywnych poszukiwań nowej literatury na nowe czasy, która zmierzyłaby się z trzema szeroko dyskutowanymi problemami: politycznym zaangażowaniem, rolą społeczną i autoreferencyjnością literatury. Nie były to problemy nowe, ale po 1989 roku powróciły one ze zdwojoną siłą w kontekście kontrowersji wokół nowych historycznych, politycznych i estetycznych wzorców interpretacyjnych pozjednoczeniowej rzeczywistości. Przybrały one postać tzw. niemiecko-niemieckiego sporu literackiego, który w czerwcu 1990 roku zainicjowały dwie wpływowe postacie w zachodnioniemieckim życiu literackim: Ulrich Greiner, szef działu felietonu w tygodniku „Die Zeit”, oraz Frank Schirrmacher, szef działu literackiego w dzienniku „Frankfurter Allgemeine Zeitung”. Ostra krytyka skierowana przez nich pod adresem Christy Wolf - podówczas najbardziej znanej w RFN pisarki z NRD - w związku z oczekiwaną publikacją jej opowiadania Was bleibt (Co pozostanie, 1991) wywołała dotąd niezakończoną debatę, która nie dotyczyła tylko Christy Wolf, jej pozycji w NRD i roli, jaką odegrała podczas przełomu. Zataczająca coraz szersze kręgi 
dyskusja stała się bowiem okazją do formułowania postulatów dotyczących tego, jaka ma być wspólna literatura niemiecka. Najważniejszym z nich było odejście od zaangażowania politycznego i skupienie się na jej wymiarze estetycznym. Taki był sens zadekretowanego przez Ulricha Greinera końca „estetyki moralności” (Gesinnungsästhetik), czyli zakończenia mariażu literatury z moralnością i powrotu do koncepcji autonomii literackiego dzieła sztuki'.

W tym kierunku zmierzały poszukiwania takich autorów, którzy w swojej twórczości dystansowaliby się zarówno od uważanych za zdezaktualizowane wzorców estetycznych literatury zachodnioniemieckiej lat siedemdziesiątych i osiemdziesiątych, jak też od uprawianego w NRD realizmu. Te nadzieje zdawał się spełniać Durs Grünbein, urodzony w 1962 roku w Dreźnie poeta, który na początku lat dziewięćdziesiątych miał już na koncie dwie dobrze przyjęte przez krytykę publikacje: debiutancki, wydany w 1988 roku tom Grauzone morgens (Strefa szarości o poranku) oraz Schädelbasislektion (Lekcja podstawy czaszki) z roku 1991 (oba ukazały się w renomowanym zachodnioniemieckim wydawnictwie Suhrkampa).

Orędownicy nowej estetyki i „nowego początku” w literaturze niemieckiej, m.in. Iris Radisch i Karl Heinz Bohrer, witali Grünbeina jako poetę świeżego i oryginalnego, którego można i należy czytać nie tyle z zaciekawieniem wschodnioniemiecką egzotyką bądź z poczucia obowiązku, ile dla niego samego i jego poetyckiego kunsztu. Dla wpływowych na początku lat dziewięćdziesiątych krytyków i publicystów: Franka Schirrmachera i Gustava Seibta był on „pierwszym prawdziwym głosem nowej Republiki”, „ulubieńcem bogów” porównywalnym z Hofmannsthalem oraz „najlepszym kandydatem na stanowisko niemieckiego poety narodowego" (cyt. za: Young 2013: 9-10).

Grünbein nie stał się gwiazdą jednego sezonu. Przeciwnie, dziś należy do najlepiej rozpoznawalnych współczesnych poetów niemieckich, którego utwory cieszą się uznaniem nie tylko w Niemczech, ale także - poprzez przekłady - daleko poza ich granicami². Jego twórczość budzi nieprzerwanie zainteresowanie publiczności literackiej oraz fachowych kręgów literaturoznawców i krytyków, o czym świadczy imponująca liczba poświęconych jej studiów i opracowań

1 Obszerną dokumentację niemiecko-niemieckiego sporu o literaturę zawiera publikacja Anz, Bolay, red. 1995.

2 Z pokaźnego dorobku Dursa Grünbeina przetłumaczono do tej pory na język polski niewiele: wybór esejów i wywiadów Wulkan i Wiersz (2010), Mizantrop na Capri. Historie/Wiersze. Der Misanthrop auf Capri. Historien/Gedichte (2012), garść wierszy W „Odrze” (1996/5), „Kwartalniku Artystycznym” (1998/4) oraz „Literaturze na Świecie” (1998/3; 2011/7-8; 2014/1-2; 2015/5-6). 
(m.in. Berg 2007; Eskin 2013; Horst, Seidler 2015; Pabst 2016; Eskin 2020). Ta obfitość jest też, jak sądzę, świadectwem toczącej się nieprzerwanie dyskusji nad kształtem współczesnej sceny literackiej w Niemczech, na której Grünbein jest postacią pierwszoplanową.

\section{Cel artykułu i wstępne uwagi}

W artykule zamierzam przedstawić - głównie w oparciu o eseistykę i wypowiedzi o charakterze autotematycznym Grünbeina - proces kształtowania się w latach dziewięćdziesiątych jego samoświadomości jako artysty. Był to czas, gdy gwałtownie zmieniająca się rzeczywistość wymuszała na pisarzach, zwłaszcza tych, którzy pochodzili ze wschodu Niemiec, modyfikowanie bądź budowanie strategii życiowych i artystycznych, które zapewniłyby im byt na kształtującym się na nowo rynku literackim. Lata dziewięćdziesiąte były dla Grünbeina okresem poszukiwania odpowiednich środków wyrazu artystycznego. Sceptycyzm wobec wszelkich koncepcji teoretycznych, mód i oczekiwań, który podówczas wyrażał w różnych wypowiedziach, jest w myśleniu Grünbeina o literaturze stale obecny. Dowodzą tego m.in. jego wykłady z poetyki, w których przekornie dowodzi, że... wszelkie teoretyzowanie w tej dziedzinie jest zbędne. Jego zdaniem poeta nie powinien zajmować się teorią, ponieważ „łatwo zaczyna się gubić w gąszczu zbyt jednoznacznych definicji i schodzi z jedynej możliwej drogi, czyli drogi własnej praktyki, która w znacznej części składa się z procesów toczących się w podświadomości oraz z dużej porcji szczęśliwego trafu" (Grünbein 2012: 42) 3 $^{3}$ W kolejnych podpunktach przedstawię zagadnienia dominujące w twórczości Grünbeina w latach dziewięćdziesiątych: stosunek do własnej biografii, do tradycji europejskiego modernizmu i antyku oraz refleksję nad własną sztuką pisarską. Prezentację tych zagadnień poprzedzę czterema uwagami odnoszącymi się do jego całej twórczości.

Po pierwsze, Grünbein nieustannie poddaje swoją twórczość niekiedy bardzo krytycznej samoocenie. Jako przykład może tu posłużyć wywiad z 2006 roku, w którym poeta zdecydowanie odciął się od swoich pierwszych publikacji: „Początek mojego pisania miał miejsce na innej planecie. Dzisiaj te teksty wydają mi się archiwalnymi filmami; ich linijki migają czernią i bielą. Ich czytanie na głos jest dla mnie niemożliwością. Ich forma i historia powstania stały mi się obce" (Durs Grünbein in Conversation... 2013: 20).

3 Wszystkie tłumaczenia cytatów pochodzą, o ile nie podano nazwisk tłumaczy, od autora artykułu. 
Po drugie, Grünbein jest poetą oraz eseistą, przy czym jego nasyconej refleksjami poetologicznymi eseistyki nie należy traktować jako komentarza do wierszy albo wręcz instrukcji, jak je należy pisać. Często natomiast wiersz staje się przedłużeniem eseju.

Po trzecie, stałym elementem myślenia Grünbeina o literaturze jest przekonanie, że jej zadaniem nie jest prosty opis rzeczywistości albo jej odzwierciedlenie i że nie może ona pełnić roli służebnej wobec polityki: „Poezja nie jest deserem polityki, ona jest prawdą, która stoi za wszelką polityką" (por. Young 2013: 19). W uprawianiu poezji chodzi zawsze o coś więcej niż tylko reakcję na bieżące wydarzenia; niekiedy jest to - zwłaszcza we wczesnych latach dziewięćdziesiątych, gdy poeta zajmował się intensywnie fenomenologią, epistemologią oraz obrazowym charakterem percepcji - „ogląd” (Anschauung), „rekonesans” (Erkundung $)^{4}$ oraz pamięć o zapisanych w ciele szokujących doświadczeniach przeszłości, które poezja wydobywa na światło dzienne dzięki łączącym doświadczenie z historią aktom "nagłej iluminacji” (sudden illuminations) (por. Durs Grünbein in Conversation... 2013: 220). W procesie twórczym Grünbeina interesuje to, co według klasyka fotoreportażu Henri Cartier-Bressona jest decydującym momentem, oraz to, co Roland Barthes nazywał punctum, czyli opowiadaniem historii dziejącej się poza obrazem (por. Grünbein 2014).

Po czwarte, ukształtowany w latach dziewięćdziesiątych sposób myślenia Grünbeina o literaturze, jej stosunku do rzeczywistości i byciu poetą we współczesnym świecie nie uległ w gruncie rzeczy zmianie, chociaż nie brak w nim niekonsekwencji wynikających z zasadniczej sprzeczności między dążeniem do autonomii artysty a jego uwikłaniem w historię, o czym będzie jeszcze mowa w ostatniej części artykułu.

\section{Początki kariery: poeta $\mathrm{z}$ niechcianym rodowodem}

Grünbein pojawił się na literackiej scenie w odpowiednim momencie, jednakże spektakularny początek literackiej kariery zawdzięcza on chyba przede wszystkim protekcji Heinera Müllera, wybitnego, doskonale funkcjonującego w obiegach literackich obu państw niemieckich dramaturga i reżysera teatralnego, który w stosunku do młodego poety pełnił rolę mecenasa i krytycznego interlokutora. To właśnie Müller doprowadził do opublikowania debiutanckiego tomu wierszy Grünbeina, dla którego twórczość dramatyczna autora

4 Na temat związków poetyki Grünbeina $z$ filozoficzną fenomenologią i jego zainteresowania jej czołowymi przedstawicielami: Maurice Merleau-Pontym, Edmundem Husserlem i Gastonem Bachelardem zob. Ahrend 2015. 
Hamletmaszyny stanowiła ważny punkt odniesienia w procesie kształtowania własnego stosunku do historii ${ }^{5}$. W laudacji wygłoszonej z okazji przyznania Grünbeinowi w 1995 roku prestiżowej nagrody im. Georga Büchnera Müller przedstawił swojego podopiecznego jako reprezentanta nowego pokolenia twórców, wskazując jednocześnie, na przykładzie wiersza Portrait des Künstlers als junger Grenzhund (Portret artysty jako młodego psa wartowniczego), na charakterystyczne cechy jego twórczości:

W wierszu Grünbeina nabrało kształtu doświadczenie pokoleniowe, które do tej pory wyrażało się raczej jako odrzucenie formy. Jest to pokolenie nieumarłych zimnej wojny, które nie pojmuje już historii jako nadawania sensu bezsensowi przy pomocy ideologii, lecz tylko jako bezsens. [...] Jego [Grünbeina - J.K.] obrazy są zdjęciami rentgenowskimi, a wiersze cieniami wierszy, rzuconymi na papier niczym błysk atomu. Tajemnicą jego płodności jest nienasycona ciekawość katastrof, które ma na podorędziu to stulecie, zarówno pod gwiazdami, jak i pod mikroskopem (Müller, dostęp 2020).

W następstwie zmiany pokoleniowej na rynek literacki w latach dziewięćdziesiątych weszli autorzy urodzeni w latach pięćdziesiątych i sześćdziesiątych, których twórczość - bardzo zróżnicowana tematycznie, formalnie i estetycznie wykazuje także podobieństwa, wspomniane przez Müllera. Tym, co ich łączy, jest doświadczenie końca historii, wielkich projektów ideologicznych i wielkich narracji. Wynikający z tego doświadczenia dystans wobec rzeczywistości społecznej i politycznej odróżnia tych twórców zdecydowanie od pokolenia pisarzy debiutujących we wczesnych latach sześćdziesiątych (m.in. od Güntera Grassa, Hansa Magnusa Enzensbergera i Güntera Kunerta), które rzeczywistość chciało zmieniać6.

5 Heinerowi Müllerowi Grünbein poświęcił trzy wiersze w opublikowanym w 1999 roku tomie poetyckim Nach den Satiren. Wiersze te: Zum Abschied Heiner Müller (Na pożegnanie Heinera Müllera), Heiner Müller auf dann... Drei Blätter (No to na razie, Heiner Müller... Trzy kartki) oraz Brief an einen toten Dichter (List do martwego poety) mają charakter rozrachunkowy; śmierć dramaturga była w ujęciu Grünbeina końcem teatru jako miejsca, w którym uprawia się historiografię.

6 Potencjał analityczny kategorii pokolenia w odniesieniu do literatury współczesnej, szczególnie literatury niemieckiej po 1989 roku, nie został jeszcze - jak sądzę - w pełni wykorzystany. Warto w tym kontekście odnotować próby stworzenia modeli generacyjnych społeczeństwa wschodnioniemieckiego przez socjologów (por. Ahbe, Gries 2015) oraz wschodnioniemieckiego środowiska literackiego (por. Meuser, Ludwig 2014). 
Interpretacje twórczości Grünbeina w latach dziewięćdziesiątych, zwłaszcza w pierwszej połowie dekady, zmierzały - najogólniej rzecz ujmując - w dwóch kierunkach. Przedstawiano go bądź to jako przedstawiciela nowej estetyki, zachowującej wobec rzeczywistości chłodny dystans, bądź to jako dziecko zimnej wojny, które dzięki literackim umiejętnościom (i moralnemu zobowiązaniu) potrafi przedstawić mroczny świat dzieciństwa i wczesnej młodości w państwie totalitarnym. Lektura tekstów Grünbeina zarówno pochodzących $z$ lat dziewięćdziesiątych, jak i późniejszych nakazuje weryfikację tego podejścia i potraktowanie aspektu estetycznego i historycznego jego twórczości łącznie, mimo jego deklaracji i oświadczeń z wczesnych lat dziewięćdziesiątych, które mogłyby sugerować jedno z wymienionych odczytań jego intencji.

Młody poeta bronił się przed próbami kojarzenia go z konkretnym środowiskiem literackim, przede wszystkim zaś przed zaszufladkowaniem go jako przedstawiciela tzw. literatury postenerdowskiej. Wypowiedziami, takimi jak na przykład wywiad, którego w 1991 roku udzielił opiniotwórczemu dziennikowi zachodnioniemieckiemu „Frankfurter Allgemeine Zeitung”, Grünbein starał się rozwiewać oczekiwania, że z racji swojego pochodzenia wpisze się w nurt literatury rozrachunkowej z państwem wschodnioniemieckim i z własną biografią: „Kimże ja jestem, że mówię w ten sposób? Urodzony w 1962 roku w Dreźnie i nie kopany po jajach przez służbę bezpieczeństwa, jestem w najlepszym razie estetycznym idiotą, politycznym mutantem i geograficznym Obcym" (Grünbein 1991)'.

Obce było mu również poczucie nostalgii po utraconym kraju pochodzenia, która na przełomie lat dziewięćdziesiątych i dwutysięcznych przybrała w literaturze niemieckiej specyficzną formę tzw. ostalgii. Odcinał się od niej zdecydowanie, tak jak od opozycyjności:

Socjalizm był dla mnie koszmarem [...] - stwierdził w wywiadzie z 2006 roku dla „Neue Zürcher Zeitung” - Chciałem się tylko stamtąd jakoś wydostać. Nigdy nie tęskniłem za NRD i nigdy nie zrozumiałem ostalgii. Chciałem zwiedzać muzea na świecie, kościoły i miasta. Wszystko inne było mi obojętne (cyt. za: Young 2013: 20).

7 Słowo idiota jest tu nawiązaniem do Arystotelesowskiego rozróżnienia między „zoon politikon”, czyli „zwierzęciem politycznym”, tj. człowiekiem zainteresowanym sprawami publicznymi i aktywnie w życiu publicznym uczestniczącym, a „idiotes”, czyli kimś skupionym wyłącznie na życiu prywatnym, w tym przypadku także na kwestiach estetycznych. 
Ostentacyjne dystansowanie się Grünbeina od NRD jako kraju pochodzenia i od wszelkich, rzekomo z tego faktu wynikających, powinności artysty nie oznaczało bynajmniej wykluczenia wschodnioniemieckiej problematyki z jego liryki i eseistyki. Przeciwnie, jest ona w jego twórczości obecna przez całe lata dziewięćdziesiąte - tyle tylko że poza ówcześnie głównymi nurtami literatury zajmującej się enerdowską przeszłością, czyli dokumentalnym, rozrachunkowym i nostalgicznym (por. Cosentino 2000).

\section{Związki z modernizmem}

Ostatnie lata istnienia NRD Grünbein spędził w Berlinie, do którego przeniósł się z Drezna jako początkujący poeta, „odcięty od całej klasycznej (i współczesnej) tradycji, w próżni społeczeństwa, które dopuszczało istnienie literatury jako ideologicznej usługi" (Grünbein 2012: 13-14). Wzorem i punktem orientacyjnym dla szukającego nawiązań do tradycji „młodego barbarzyńcy” stał się Arthur Rimbaud jako bezlitosny krytyk istniejących form lirycznych i inicjator „dzikich wybryków moderny” (por. Grünbein 2012: 15). To właśnie Rimbaud miał ośmielić Grünbeina do podjęcia własnych prób poetyckich. Literacką socjalizację poeta zaczął od epiki i od autorów uważanych przezeń za outsiderów, „euforycznych metaforyków, wielowarstwowych artystów słowa, salamandry ekspresji, pionierów iluminowanej imaginacji”, do których zaliczał m.in. Brunona Schulza, Carlo Emilio Gaddę i Izaaka Babla (por. Grünbein 2012: 15). Natomiast wśród poetów lirycznych pociągali go ci, którzy odrzucali logikę języka i rozsadzali „żelazną skorupę gramatyki”, m.in. Georg Trakl, Novalis, Georg Heym, Jakob van Hoddis, Ivan Goll, Guillaume Apollinaire i młody Gottfried Benn (por. Grünbein 2012: 27). Specyficzna relacja łącząca Grünbeina z tymi i wieloma innymi autorami i artystami reprezentującymi różne dziedziny sztuki polegała i nadal polega nie tyle na bezpośredniej inspiracji i przejmowaniu określonych form czy środków wyrazu, ile raczej na podpatrywaniu poprzedników przy pracy i nawiązywaniu z nimi dialogu, któremu towarzyszy namysł nad własną sztuką poetycką. Zapis tego dialogu m.in. z takimi poetami jak Ezra Pound, George Elliot i Osip Mandelsztam odnajdujemy zarówno w jego utworach poetyckich, jak też w esejach ${ }^{8}$. Natomiast zainteresowanie Grünbeina twórczością takich artystów jak m.in. Andrea Mantegna, Kurt Seligman, Joseph Beuys i Marcel Duchamp oraz towarzyszące mu eksperymenty z ekfrazą miały swoje źródło

8 Por. m.in. tomy: Porzellan (Grünbein 2005) oraz Gedicht und Geheimnis (Grünbein 2007), w których znajdziemy ślady takiego dialogu z Goethem, Rilkem, Bennem, Celanem, Elliotem i Szekspirem. 
w jego zaciekawieniu sztuką konceptualną i sposobami organizacji procesu twórczego przez jej przedstawicieli ${ }^{9}$.

Nawiązywanie do tradycji europejskiego modernizmu przez twórców żyjących w społeczeństwie zamkniętym, jakim było społeczeństwo wschodnioniemieckie, oznaczało także poszukiwanie tożsamości kulturowej, zagubionej w następstwie izolacji. W przypadku Grünbeina poczucie bycia Europejczykiem nabrało mocy dzięki podróżom za ocean: „Dopiero dzisiaj, po wielokrotnych pobytach w Ameryce, czuję się znów jak świeżo upieczony Europejczyk" (cyt. za: Eskin 2013: 24). Co więcej, Grünbein mówi o sobie raczej jako o poecie języka niemieckiego niż jako o poecie niemieckim (por. Eskin i in. 2013: 234), podkreślając w ten sposób swoje zakorzenienie w kulturze europejskiej.

W drugiej połowie lat dziewięćdziesiątych Grünbein - podobnie zresztą jak wielu innych twórców pochodzących ze wschodnich Niemiec, m.in. Wolfgang Hilbig i Reinhard Jirgl - stopniowo nabierał dystansu do modernizmu. W warstwie deklaratywnej odciął się od niego zdecydowanie w wygłoszonych w 2009 roku wykładach z poetyki, w których określił modernizm jako kierunek dogmatyczny, który przez wywieranie ciągłej presji na innowacyjność raczej szkodzi poezji, niż jej pomaga (por. Grünbein 2012: 46-47). W praktyce poeta nie odrzucił tej tradycji całkowicie, a czołowi przedstawicie modernizmu są dlań nadal autorami, do których dorobku się odwołuje.

\section{Poetyka fragmentu w tomach: Grauzone morgens (1988) i Schädelbasislektion (1991)}

Poetykę i praktykę poetycką Grünbeina we wczesnych latach dziewięćdziesiątych determinowało postrzeganie rzeczywistości jako fragmentarycznej. Równie ważna była dlań rola fizyczności w procesie twórczym. W tym okresie było mu blisko do modernistów Ezry Pounda i Charlesa Baudelaire’a, których eksperymenty formalne (forma wiersza w Cantos Pounda, Baudelairowska postać flaneura) miały wpływ na jego metodę zbliżenia się do rzeczywistości polegającą na kumulacji pojedynczych wrażeń, gęsto przetykanych różnego rodzaju wtrąceniami. Pierwsze zbiory swoich wierszy: Grauzone morgens, Schädelbasislektion oraz Falten und Fallen (Fałdy i pułapki) Grünbein przedstawiał jako poetyckie fragmenty, w których niedopasowane elementy zostały zmontowane w nieoczywisty sposób (por. Grünbein 1996: 19).

9 Na temat sceptycznego stosunku Grünbeina do przekładalności obrazów na słowa zob. m.in. Grünbein, Jocks 2011. 
Pochodzący z debiutanckiego tomu Grauzone morgens cykl wierszy pod tym samym tytułem jest sekwencją migawkowych ujęć Drezna, które sam autor nazwał później prowincjonalnymi impresjami (por. Grünbein 1992). Porannej przechadzce po „strefie szarości” patronują dwaj poeci: wspomniany wyżej Baudelaire („Strefa szarości o poranku, mon frère...” (Grünbein 2006: 12)) oraz wędrowiec przemierzający kolejne kręgi piekła, czyli Dante Alighieri („Czy znają Państwo Dantego?” (Grünbein 20o6: 18)). Baudelairowska postawa niezaangażowanego obserwatora oraz właściwe Dantemu postrzeganie rzeczywistości jako fragmentarycznej pozwoliły Grünbeinowi na ukazanie zastygłego w bezruchu świata na chwilę przed jego rozpadem: „Strefa szarości o poranku / wszystko jest najpierw / martwym chaosem zastałych obrazów, $\mathrm{np}$. / odrobiną piany po goleniu w / rynsztoku, obrożą / albo znakiem zakazu na drodze" (Grünbein 2006: 24).

Reakcja Grünbeina na doświadczenie przełomu i transformacji ustrojowej polegała na próbie wypracowania estetyki zrywającej z koncepcją literatury zaangażowanej społecznie, za to zaangażowanej na rzecz swobodnej ekspresji twórczej, której nie da się ująć w żadne ramy ideowe bądź instytucjonalne.

Drugi, opublikowany w 1991 roku tom poetycki Schädelbasislektion przynosi obraz świata, w którym czas gwałtownie przyspieszył, a nową, pozjednoczeniową rzeczywistość tworzy niezliczona ilość fragmentów, których nie ma komu poskładać w całość. Z rozbiciem rzeczywistości szła bowiem w parze dezintegracja podmiotu, tak jak w wierszu In Tunneln der U-Bahn (W tunelach metra):

[...] a kim ja byłem: / dozwolonym Ja, / Martwym punktem albo końcówką sylaby... (-nie), / roztrzaskany i ponownie zjednoczony / $\mathrm{w}$ uniwersum // z dnia na dzień, / podtrzymywany przez pas przepuklinowy godzin / sklecony / kawałkami / i we fragmentach / 'Ich feel so atomized' (Grünbein 2006: 119).

O ile w tomie Grauzone morgens ,ja” liryczne jest obserwatorem, który ze stoickim spokojem patrzy na rzeczywistość, o tyle w Schädelbasislektion jest to ktoś anonimowy, nieokreślony, kto nie jest w stanie sobie poradzić z gwarem dobiegających doń zewsząa głosów. Fragmentaryczność rzeczywistości przybiera w tym tomie postać polifonii, którą odbiera anonimowa instancja usadowiona „W miejscu spotkania wielu głosów” (Grünbein 1996: 46).

Status podmiotu lirycznego i tożsamość twórcy jako świadka czasu jest dla Grünbeina jednym z powracających tematów poruszanych przezeń w kontekście refleksji nad sztuką poetycką. Zdaniem poety świadek czasu wie tyle samo co inni ludzie, a zdarzenia, które obserwuje, są dlań takim samym zaskoczeniem 
jak dla przeciętnego widza. „Stałem na poboczu, gdy to się działo, i przecierałem oczy" - tak poeta wspomina swoją reakcję na historyczne wydarzenia jesienią 1989 roku (Eskin 2020: 49). „Świadek czasu” jest dla Grünbeina kategorią wewnętrzną, indywidualną; to ktoś, z kim toczy nieustanny dialog prowadzący w zamierzeniu do samozrozumienia: „Widzę siebie raczej jako zakamuflowanego badacza moich okoliczności życiowych. Od czasu do czasu rozmawiam ze świadkiem czasu, który jest we mnie. Pilnuję jednak, aby nie miał on ostatniego słowa” (Eskin 2020: 50) ${ }^{10}$.

Połączenie elementów autobiograficznych z perspektywą obserwatora rzeczywistości jest swego rodzaju „znakiem firmowym” twórczości Grünbeina. Jego zdaniem podmiot w tekstach poetyckich może przybierać różną postać; niekiedy jest to „ja” bardzo mu bliskie, innym razem odległe, postać historyczna albo pierwszoosobowy narrator dziennika. „Ja” obserwujące rzeczywistość w wierszach Grünbeina z lat dziewięćdziesiątych bywa niekiedy kimś, kto ukradkiem robi poruszone czarno-białe zdjęcia drezdeńskich ulic (por. Grünbein 2012: 19), innym zaś razem, tak jak w wierszu 1989 z tomu Nach den Satiren (Po satyrach), jest telewidzem, który z okazji kolejnej rocznicy upadku muru berlińskiego ogląda w telewizji dobrze mu znane obrazy, starając się ująć związane z nimi wrażenia i wspomnienia w językową formę.

\section{Neuro-poetyka}

W poetyce Grünbeina we wczesnych latach dziewięćdziesiątych drugim, obok fragmentaryczności rzeczywistości, motywem przewodnim jest ścisły związek między artykułowanym w języku postrzeganiem rzeczywistości a czysto fizycznymi doznaniami. U podłoża zainteresowania poety ciałem i cielesnością leży zapewne renesans antropologii zarówno w naukach przyrodniczych, jak też w naukach o kulturze. Przyniósł on także koniunkturę problematyki ciała i fizyczności w literaturze tego okresu jako ostatniej instancji gwarantującej autentyczność i naturalność doświadczania rzeczywistości.

10 Bycie świadkiem czasu ma we współczesnej refleksji Grünbeina także wymiar moralny i etyczny. Słowem-kluczem do poezji Celana jest dlań „wstyd” odczuwany na myśl o powszechnej niewiedzy i braku wyobraźni w stosunku do ofiar wojny: „Bezbronni ludzie, cywile są zabijani w cieniu wojny, a większości ludzi z wyraźnie wielkim trudem przychodzi postawienie się na ich miejscu" (zob. Eskin 2020: 16). Podobny wymiar ma też próba odpowiedzi na pytanie, czy człowiek urodzony wiele lat po wojnie ma prawo do wydawania osądów moralnych wobec ludzi uwikłanych w tragiczne wydarzenia historyczne, takie jak zniszczenie Drezna (por. wiersze w tomie Porzellan). 
W eseju Mein babylonisches Hirn (Mój babiloński mózg) z 1991 roku Grünbein sięgnął do koncepcji engramu jako językowo-fizjologicznego zapisu wrażeń w pamięci. Jego zdaniem poeta nie powinien ograniczać się do namysłu nad językiem i sposobami jego używania, lecz poszukiwać fizycznej podstawy swojej twórczości, ponieważ to „ciało decyduje o tym, co jest metodą” (Grünbein 2007: 33).

Zgodnie z tą koncepcją poeta nie ma gotowego zasobu słów bądź zestawu obrazów, lecz znajduje je dopiero w fizycznym zetknięciu ze światem zewnętrznym. „Wszelkie skuteczne pisanie - powiada Grünbein - bierze swój początek, w co wierzę niezachwianie, w ciele" (Grünbein 1996: 40), a człowiek jest tym tylko, „co na krawędzi / Anatomicznej tablicy / Spisane” (Grünbein 2006: 101)" Zawarte głównie w opublikowanym w 1996 roku zbiorze esejów Galilei vermißt Dantes Hölle und bleibt an den Maßen hängen. Aufsätze 1989-1995 (Galilusz obmierza piekło Dantego i trzyma się wymiarów. Rozprawy 1989-1995) oraz w wywiadach i rozmowach z tego okresu refleksje Grünbeina składają się na oryginalną ",neuro-poetykę", wariant antropologicznego redukcjonizmu, która polega na wydobywaniu ułomków pamięci z wnętrza kruchego i nietrwałego ciała (por. Grünbein 2006: 331). Zadaniem poety jest „docieranie do głębokich pokładów mózgu, pozostawianie znaków w postaci oryginalnych engramów” a poetyką przyszłości jest neurologia (por. Grünbein 1996: 20-21).

W przemówieniu pt. Den Körper zerbrechen (Rozbijać ciało) wygłoszonym w 1995 roku z okazji przyznania nagrody im. Georga Büchnera Grünbein dokonał bilansu swojej dotychczasowej drogi artystycznej, przedstawiając ją jako krytyczną reakcję na ideologię komunizmu, która w znanym mu wariancie wschodnioniemieckim oznaczała „fizjologiczną dyktaturę i długoletnie zbiorowe upokorzenie” (Grünbein 1995).

Praktyczna realizacja założeń „neuro-poetyki” prowadziła do redukcji tego, co zwykło się nazywać wolną wolą, racjonalnym myśleniem itd., do zjawisk czysto fizjologicznych. „Człowiek był sumą odruchów Pawłowa i tyle. [...] Osobowość socjalistyczna [...] była w rzeczywistości [...] nowoczesnym wariantem tresury psa Pawłowa" - czytamy w eseju Drei Briefe (Trzy listy) poświęconym refleksji nad życiem w socjalizmie i nad istotą socjalistycznego wychowania (por. Grünbein 1996: 47-49). Jego podstawą było drobiazgowe zaplanowanie każdej chwili życia wychowanków - „od kaszlnięcia aż do świadectwa ukończenia szkoły, / od mleka, w którym jeszcze pływała prawda, aż do uleczonej jaźni” (Grünbein 2006: 145).

11 Wers w przekładzie Jakuba Ekiera. 
Zdaniem poety klucza do zrozumienia życia we wschodnich Niemczech dostarcza Pawłow, a nie Freud. „Być psem, znaczy musieć, gdy nie chcesz, Chcieć / Gdy nie możesz i ciągle ktoś się przygląda" - czytamy w wierszu otwierającym cykl Portrait des Künstlers als junger Grenzhund w zbiorze Schädelbasislektion (Grünbein 2006: 185). Pies szkolony do służby wartowniczej przy murze berlińskim jest także metaforą życia w socjalizmie. Pilnuje on bowiem nie tylko granicy państwowej, lecz także granic własnej tożsamości:

Na Zachodzie, powiadają, pies idzie przed panem. / Na Wschodzie idzie za nim - w odstępie. / Jeśli o mnie chodzi, to byłem moim własnym psem, / Jednakowo odległym od Wschodu i Zachodu, w strefie śmierci. / Tylko tutaj udawał mi się czasem ten skok / Głęboko z półmroku między psem a wilkiem (Grünbein 2006: 191).

\section{Poetyka sarkazmu}

Połączenie poezji z nauką, konkretnie z naukami przyrodniczymi można interpretować jako poszukiwanie jakiejś trzeciej drogi między uprawianiem literatury jako sztuki dla sztuki a jej zaangażowaniem społecznym i politycznym (por. Grünbein 1996: 13). Była to reakcja Grünbeina na doświadczenie pokoleniowe upadku systemu politycznego, do którego on i jego rówieśnicy podchodzili bez żadnych emocji (por. Grünbein 2009: 6). Poetę spoglądającego na rzeczywistość przenikliwym okiem fizjologa Grünbein wyposażył w narzędzie badawcze, którym jest sarkazm. Koncepcję poezji sarkastycznej, krytycznej wobec wszelkich ideologii i utopii Grünbein sformułował na początku lat dziewięćdziesiątych w korespondencji z pisarzem Marcelem Beyerem (zob. Berg 2007: 32). Dekadę później opisał istotę sarkazmu, sięgając do jego greckiego źródłosłowu. Sarkazein to słowo nazywające czynność oddzielania mięsa od kości. Według poety opisuje ono „ową nieuniknioną zwierzęcą redukcję, dobieranie się, przy pomocy zębów, rąk i noży, do kości, ości i szpiku” (Grünbein 2001: 63). Założenia „poetyki sarkazmu" polegającej na odrzucaniu wszelkich sensów ideologicznych i utopijnych, aby tym uważniej przyglądać się człowiekowi jako istocie biologicznej, Grünbein zrealizował najpełniej w cyklach O Heimat zynischer Euphon (Ojczyno, cyniczne eufonium) i Portrait des Künstlers als junger Grenzhund wchodzących w skład tomu Schädelbasislektion, w cyklu Mensch ohne Großhirn (Człowiek bez kresomózgowia) w tomie Falten und Fallen oraz w cyklu Europa nach dem letzten Regen (Europa po ostatnim deszczu) w tomie Nach den Satiren. W jego publikacjach $\mathrm{z}$ lat dwutysięcznych, takich jak m.in. tomy poezji: Erklärte Nacht (Noc ogłoszona, 2002) oraz Strophen für übermorgen (Strofy 
na pojutrze, 2007), sarkazm jest już łagodzony ironią, co zapewne ma związek z porzuceniem przez Grünbeina języka dyskursu fizjologicznego i odejściem od założeń neuro-poetyki.

\section{Zwrot ku przeszłości: Nach den Satiren (1999)}

Ciągłość namysłu Grünbeina nad istotą poezji i rewizji własnego stosunku do tradycji literackich nasuwa przypuszczenie, że była to forma „ucieczki do przodu" umotywowana pragnieniem uwolnienia się od przymusu samookreślenia się jako artysta, którego można przypisać do jakiegoś nurtu bądź tendencji. W autokomentarzu do swojej twórczości z lat dziewięćdziesiątych Grünbein stwierdził, że:

Widocznie NRD od początku była o wiele za mała dla mojej wyobraźni. Później o wiele za mała stała się dla mnie także konkretna zachodnia kultura codzienna, widziana w świetle modernizmu. To był moment, gdy musiałem zanurzyć się w antyku, w czasach baroku, w starożytnym Rzymie, dotrzeć do Baudelaire’a, Lautrémonta itd. Nagle Kolumb zaczął zerkać mi przez ramię, latające ryby zatrzepotały w rynsztoku, a tuż za drzwiami leżały wyspy Indii Zachodnich (Eskin 2020: 27).

Ślady dyskursu anatomii i neurologii będą się jeszcze pojawiały w wierszach, natomiast praktykowany zwłaszcza w tomie Schädelbasislektion redukcjonizm fizjologiczny znika z myślenia Grünbeina o poezji całkowicie. Zapisem wyraźnego przesunięcia akcentów w jego poetyce jest tom wierszy Nach den Satiren ${ }^{12}$. Sprawą pierwszorzędnej wagi staje się forma wiersza, którą poeta ma - jak to Grünbein postuluje m.in. w nieco wcześniejszym eseju Vulkan und Gedicht (Wulkan i wiersz) (Grünbein 1996: 34-39) - wydobywać spod warstw czasu. Użycie metaforyki archeologicznej nie świadczy jednak o zamiarze poetyckiej rekonstrukcji antyku w jego pierwotnej wersji. Sięgając do klasycznych form literackich, takich jak elegia, oda, sonet i poemat epicki, Grünbein unika archaizacji i dba o to, aby nie krępowały one swobody wypowiedzi w języku współczesnym. Dla niego antyk jest rezerwuarem ludzkich uczuć i motywów działania, takich samych jak obecnie. Zasadą kompozycyjną wierszy zebranych

12 Tytuł tomu jest dwuznaczny. Można go bowiem interpretować jako „po satyrach” albo jako „w stylu/manierze satyr”. Grünbein jako twórca „poetyki sarkazmu” nie jest naśladowcą Juwenalisa, dlatego skłaniam się ku pierwszej wersji tytułu wskazującej na postsatyryczny charakter jego wierszy. 
w drugiej części tomu Nach den Satiren jest symultaniczność historycznych warstw czasu, dzięki której widoczne staje się to, co w naturze ludzkiej jest stałe i niezmienne od czasów rzymskich aż do schyłku xx wieku.

\section{Stałość w zmienności i odwrotnie}

Konfrontacja twórczości Grünbeina z lat dziewięćdziesiątych z jego dorobkiem z dwóch kolejnych dziesięcioleci pozwala stwierdzić, że autora interesują niezmiennie te same problemy: autonomia literatury i swoboda twórcza oraz związki historii z pamięcią i literaturą. Trudno przy tym nie zauważyć sprzeczności w jego myśleniu, które mają swoje źródło w nieprzezwyciężalnym konflikcie między swobodą artysty a jego uwikłaniem w procesy dziejowe.

Z jednej strony Grünbein stara się bronić suwerenności literatury, stojąc na stanowisku, że uprawianie poezji powinno być czynnością ściśle indywidualną i wolną od wszelkich zewnętrznych uwarunkowań. „Pisanie wierszy - powiada, mając na myśli własną praktykę pisarską - jest chyba przede wszystkim ćwiczeniem w radykalnym samopoznaniu” (Grünbein 2019: 10) poety, który powinien być nonkonformistą i pozostawać „eremitą w społeczeństwie” (Grünbein 2019: 13). Język poezji nie jest - jak to Grünbein podkreśla w syntetycznym wykładzie własnej poetyki w minieseju Das Punktum des Gedichts (Punctum wiersza) - językiem nauki, religii, filozofii bądź mitu, lecz językiem zwyczajnym, bliskim językowi potocznemu i zrozumiałym dla każdego użytkownika (por. Grünbein 2019: 111-112). Zbliżenie języka sztuki i literatury do języka codzienności - tak przecież sponiewieranego przez media i zdeprawowanego przez polityków, co Grünbein z całą ostrością dostrzega - ma według niego konkretny cel, którym jest wciąganie widza i czytelnika w dialog z samym sobą, prowadzący do refleksji moralnej.

Z drugiej strony poeta przyznaje, że literatura nie jest w stanie obronić się przed „wielką” historią, która przenika do wszystkich, także tych najbardziej osobistych sfer życia. W swoich najnowszych publikacjach Grünbein wraca do splecionej z historią rodzinną historii Drezna na przełomie xIx i xx wieku, wojennej zagłady i powojennych dziejów miasta oraz odkrywa lokalny wymiar historii Saksonii. W ten sposób wpisuje się w szeroki i bardzo zróżnicowany nurt tzw. literatury pamięciowej (Erinnerungsliteratur), która eksploruje głównie dwudziestowieczną historię Niemiec, przynosząc jednocześnie namysł nad mechanizmami jej przypominania i sposobami przedstawiania ${ }^{13}$. Reprezentatywny

13 Używam pojęcia „literatura pamięciowa”, aby w ten sposób odróżnić ją od „literatury wspomnieniowej", kojarzącej się przede wszystkim z ego-dokumentami (pamiętnikami, dziennikami itp.). 
pod tym względem jest złożony z opowieści prozą i wierszem, refleksji i fotografii tom Die Jahre im Zoo. Ein Kaleidoskop (Lata w ogrodzie zoologicznym. Kalejdoskop) (Grünbein 2015), w którym przed oczami czytelnika pojawiają się, niczym w kalejdoskopie, obrazy przeszłości dalszej, zapisanej w pamięci kulturowej, i bliższej, utrwalonej w pamięci autora.

Przed historią nie można skryć się w jakiejś prywatnej niszy. Można próbować się z nią zmierzyć, mając nadzieję, że skutecznym środkiem okaże się „fotosynteza” słów i obrazów, o której Grünbein mówi w oksfordzkich wykładach, ilustrując swoje rozważania na temat dwudziestowiecznej historii Niemiec i Europy i jej formacyjnego wpływu na jednostkę znaczkami pocztowymi, pocztówkami i fotografiami (Grünbein 2020). Można też - wzorem Zbigniewa Herberta - szukać stałego punktu oparcia w kulturze europejskiej jako miejsca wspólnego, „w którym żyjemy wszyscy, pomimo upływu lat, zmiany mód i sposobów komunikowania”. To właśnie - zdaniem jurorów Międzynarodowej Nagrody Literackiej im Zbigniewa Herberta - konsekwentnie czyni Grünbein w całej swojej twórczości (por. Laureat Nagrody Literackiej..., dostęp 2021).

\section{| Bibliografia}

Ahrend Hinrich (2015), 'Aqua alta'. Das Meer als Ort phänomenologischer Erkenntnis bei Durs Grünbein, w: Bildlichkeit im Werk Durs Grünbeins, red. Christoph auf der Horst, Miriam Seidler, Walter de Gruyter, Berlin-Boston, s. 115-139, https://doi.org/10.1515/9783110318739-0o8.

Ahbe Thomas, Gries Rainer (2015), Historia społeczna jako historia pokoleń. Przemyślenia teoretyczne i metodologiczne na przykładzie NRD, w: Pokolenia albo porządkowanie historii, wybór, wstęp i oprac. Hubert Orłowski, przeł. Izabela Drozdowska-Broering, Jerzy Kałążny, Rafał Żytyniec, Wydawnictwo Nauka i Innowacje, Poznań, s. 593-690.

Anz Thomas, Bolay Christoph, red. (1995), „Es geht nicht um Christa Wolf“. Der Literaturstreit im vereinigten Deutschland, Fischer, Frankfurt a.M.

Berg Florian (2007), Das Gedicht über das Nichts. Über Anthropologie und Geschichte im Werk Durs Grünbeins, Königshausen und Neumann, Würzburg.

Cosentino Christine (200o), Bernd Wagners Paradies: ironisch-utopische Dimensionen in der Post-Wende-Literatur, „Seminar: A Journal of Germanic Studies", nr 4, s. 436-451, https://doi.org/10.3138/sem.v36.4.436.

Durs Grünbein in Conversation with Michael Eskin and Christopher Young: 'Cadences in the Gaps of Time.' The Poet, the Past and Porzellan (2013), w: Durs 
Grünbein. A Companion, red. Michael Eskin, Karen Leeder, Christopher Young, Walter de Gruyter, Berlin, s. 219-234.

Eskin Michael (2013), Durs Grünbein and the European Tradition, w: Durs Grünbein. A Companion, red. Michael Eskin, Karen Leeder, Christopher Young, Walter de Gruyter, Berlin, s. 23-38.

Eskin Michael (2020), Schwerer werden. Leichter sein. Gespräche um Paul Celan. Mit Durs Grünbein, Gerhard Falkner, Aris Fiorentos und Ulrike Draesner, Wallstein Verlag, Göttingen.

Fioretos Aris, Grünbein Durs (1996), Gespräch über die Zone, den Hund und die Knochen, „Akzente”, nr 43, s. 486-501.

Grünbein Durs (1991), Im Namen der Füchse. Gibt es eine neue literarische Zensur?, „Frankfurter Allgemeine Zeitung”, 26.11.

Grünbein Durs (1992), 'Poetry form the bad Side. Gespräch mit Thomas Naumann, „Sprache im technischen Zeitalter”, nr 124.

Grünbein Durs (1995), Den Kopf zerbrechen, Deutsche Akademie für Sprache und Dichtung, https://inyurl.com/yagvt6tz [dostęp: 12.12.2020].

Grünbein Durs (1996), Galilei vermißt Dantes Hölle und bleibt an den Maßen hängen. Aufsätze 1989-1995, Suhrkamp, Frankfurt a.M.

Grünbein Durs (2001), Das erste Jahr. Berliner Aufzeichnungen, Suhrkamp, Frankfurt a.M.

Grünbein Durs, Jocks Heinz-Norbert (2001), Durs Grünbein im Gespräch mit Heinz-Norbert Jocks, DuMont, Köln.

Grünbein Durs, (2005) Porzellan. Poem vom Untergang meiner Stadt, Suhrkamp, Frankfurt a.M.

Grünbein Durs (2006), Gedichte. Bücher I-III: Grauzone morgens, Schädelbasislektion, Falten und Fallen, Suhrkamp, Frankfurt a.M.

Grünbein Durs (2007), Mein babylonisches Hirn, w: tenże, Gedicht und Geheimnis. Aufsätze 1990-2006, Suhrkamp, Frankfurt a. M., s. 18-33.

Grünbein Durs (2010), Wulkan i Wiersz, przeł. Jakub Ekier, Andrzej Kopacki, Instytucja Kultury Ars Cameralis Silesiae Superioris, Katowice.

Grünbein Durs (2011), Limbische Akte: Gedichte, Reclam, Leipzig.

Grünbein Durs (2012), Vom Stellenwert der Worte. Frankfurter Poetikvorlesung 2009, Suhrkamp, Berlin.

Grünbein Durs (2014), Die Jägerin. Sieben Gedankengänge für Barbara Klemm: Fotografien Photographs 1968-2013, w: Katalog zur Ausstellung im Martin-Grophius-Bau, Berlin 16. November 2013-9. März 2014, Martin-Grophius-Bau, Berlin, s. 329-337.

Grünbein Durs (2015), Die Jahre im Zoo. Ein Kaleidoskop, Suhrkamp, Berlin. Grünbein Durs (2019), Aus der Traum (Kartei). Aufsatze und Notate, Suhrkamp, Berlin. 
Grünbein Durs (2020), Jenseits der Literatur. Oxford Lectures, Suhrkamp, Berlin. Laureat Nagrody Literackiej im. Zbigniewa Herberta, 2020, https://tinyurl.com/ y8kcmf2l [dostęp: 02.01.2021].

Meuser Mirjam, Ludwig Janine (2014), In den Kämpfen dieser Zeit - Die DDR-Literatur als Epoche literarischen Engagements und die Folgen des Umbruchs von 1989/9o im literaturhistorischen Überblick, w: Literatur ohne Land? Schreibstrategien einer DDR-Literatur im vereinten Deutschland. Mit einem Vorwort von Jost Hermand, t. 2, red. Mirjam Meuser, Janine Ludwig, Fördergemeinschaft Wiss. Publikationen von Frauen, Eschborn, s. 15-85.

Müller Heiner, Portrait des Künstlers als junger Grenzhund, https://tinyurl.com/ y7u398fs [dostęp: 04.09.2020].

Pabst Stephan (2016), Post-Ost_Moderne. Poetik nach der DDR, Wallstein Verlag, Göttingen.

Young Christopher (2013), Durs Grünbein and the Wende, w: Durs Grünbein. A Companion, red. Michael Eskin, Karen Leeder, Christopher Young, Walter de Gruyter, Berlin, s. 1-22.

\section{| Abstrakt}

JERZY KAŁĄŻNY

Literatura niemiecka po przełomie 1989/1990 roku. Przypadek Dursa Grünbeina

Urodzony w 1962 roku w Dreźnie Durs Grünbein należy do najbardziej rozpoznawalnych poetów i eseistów niemieckich w pozjednoczeniowych Niemczech. Jego liczne zbiory poezji i esejów przetłumaczono na wiele języków, m.in. angielski, francuski, rosyjski, hiszpański, japoński i polski. W artykule został przedstawiony pierwszy okres kariery Grünbeina: od debiutu w 1988 do końca lat dziewięćdziesiątych, na tle dekompozycji krajobrazu literackiego Niemiec w okresie pozjednoczeniowym. Najważniejsze zagadnienia poruszone w tym kontekście to kształtowanie się oryginalnego stylu pisarstwa i poglądów estetycznych Grünbeina, łączenie przezeń literatury z nauką oraz poetyckie opracowanie doświadczenia życia W NRD. Tradycje europejskiego modernizmu i antyku, przekonanie o potrzebie autonomii i niezaangażowania poezji oraz o fragmentarycznym charakterze doświadczenia rzeczywistości stworzyły w latach dziewięćdziesiątych fundament tożsamości artysty, który w zasadzie przetrwał nienaruszony następne dziesięciolecia.

Słowa kluczowe: Durs Grünbein; literatura niemiecka; zjednoczenie Niemiec 


\section{| Abstract \\ JERZY KAŁĄŻNY \\ German Literature and the Wende of 1989/90. The Case of Durs Grünbein}

Durs Grünbein, born 1962 in Dresden, is one of the most recognizable German poets and essayists after the German reunification. His numerous collections of poetry and prose were translated into many languages, e.g. into English, French, Russian, Spanish, Japanese and Polish. The article presents the first stage of his career since his debut in 1988 until the end of the gos against the background of the decomposition of the existing literary landscape in the unified Germany. The main focus of the paper is put on the development of the writing style and the aesthetic views of Grünbein, as well as the topics that were predominant in his early work, such as the intersection of literature and science and the poetic elaboration of the existential experience in the GDR. Traditions of European modernity and antiquity, the notion regarding the autonomy and the non-engagement of poetry, as well as the fragmentary nature of the experiencing of reality formed the basis of his poetic self-image at that time, which essentially remained unchanged in the following decades.

Keywords: Durs Grünbein; German literature; reunification of Germany

\section{| Nota o autorze}

Jerzy Kałążny - prof. zw. dr hab. w Instytucie Filologii Germańskiej. Literaturoznawca, historyk literatury niemieckiej, tłumacz. Zainteresowania badawcze: dziewiętnastowieczne procesy nation building, pamięć, narracja i tożsamość we współczesnej literaturze i historiografii, europejskie kultury pamięci w xx i xxI wieku. Najnowsza publikacja: Jak w XxI wieku opowiadać historię? Narracja jako problem teoretyczny i praktyczny $w$ niemieckich naukach o historii, kulturze i literaturze, wybór, wstęp i opracowanie Jerzy Kałążny. Przekład Jerzy Kałążny i Miłosz Wojtyna. Poznań: Wydawnictwo Nauka i Innowacje, 2019.

E-mail: jerkala@amu.edu.pl

ORCID: 0000-0002-5608-3429 